\title{
Boris Choubert: Unrecognized visionary geologist, pioneer of the global tectonics
}

\author{
${ }^{1}$ Laboratoire Magmas \& Volcans, Université d'Auvergne, Clermont-Ferrand, France \\ ${ }^{2}$ University of the Basque Country, UPV/EHU, Bilbao, Spain \\ ${ }^{3}$ Centre de Recherches Pétrologiques et Géochimiques, Nancy, France \\ ${ }^{4}$ ISTerre, Université de Grenoble Alpes, Grenoble, France \\ 5 ETH, Zürich, Switzerland \\ ${ }^{6}$ Home, 34120 Lézignan la Cèbe, France \\ ${ }^{7}$ Swedish Museum of Natural History, Stockholm, Sweden \\ ${ }^{8}$ Universidade de São Paulo, São Paulo, Brazil \\ ${ }^{9}$ Geological Survey of Canada, Ottawa, Canada \\ ${ }^{10}$ University of Oslo, Oslo, Norway \\ 11 Centre François Viète, Université de Nantes, Nantes, France \\ 12 Grant Institute, Edinburgh University, Scotland, GB
}

Jacques Kornprobst ${ }^{1, *}$, Benito Àbalos ${ }^{2}$, Pierre Barbey ${ }^{3}$, Anne-Marie Boullier ${ }^{4}$, Jean-Pierre Burg ${ }^{5}$, Ramon Capdevila ${ }^{6}$, Stefan Claesson ${ }^{7}$, Umberto Cordani ${ }^{8}$, David Corrigan ${ }^{9}$, Roy H. Gabrielsen ${ }^{10}$, José I. Gil-Ibarguchi ${ }^{2}$, Åke Johansson ${ }^{7}$, Dominik Letsch ${ }^{5}$, Philippe Le Vigouroux ${ }^{11}$ and Brian Upton ${ }^{12}$

Received: 2 March 2018 / Accepted: 27 March 2018

\begin{abstract}
This work is a review of Boris Choubert's paper (1935), which was published in French under the rather devalorizing title: "Research on the Genesis of Palaeozoic and Precambrian Belts." Despite its innovative content, this article had no impact either at the time of its publication or even later. It begins with the construction of a remarkable fit of the circum-Atlantic continents. This was based on the -1.000 meters isobath instead of the shoreline. Thirty years before Bullard et al. (1965), it demonstrated in an indisputable way the reality of the continents motion on the surface of the Earth. Therefore, Choubert designated Wegener's "continental drift" as the main cause of tectonics. Even going beyond Wegener's theory, he argued that this mechanism was efficient well before the formation of the Triassic Pangæa, during the whole Palaeozoic to result in the building of the Caledonian and Hercynian mountains. Although he was still encumbered by the vocabulary of the time regarding geosynclines, Boris Choubert described tectonics based on the horizontal mobility of the Precambrian continental blocks. Oddly enough, he did not apply this model to the Precambrian structures, which he attributed to the effects of the Earth's rotation on the continental crust during its solidification. At the time of its publication, this paper was a very important step towards understanding global tectonics. Unfortunately, Choubert's contemporaries did not generally recognize its significance.
\end{abstract}

Keywords: Wegener / continental drift / plate tectonics / orogeny / Precambrian / Palaeozoic belts

Résumé - Boris Choubert : un géologue visionnaire méconnu, pionnier de la tectonique globale. Ce travail est une analyse de l'article de Boris Choubert (1935) paru en français sous le titre un peu réducteur: «Recherches sur la genèse des chaînes paléozoïques et antécambriennes. » Malgré son contenu novateur, cet article n'a eu aucun retentissement à l'époque de sa publication, ni même plus tard. Il débute par la construction d'un remarquable assemblage des continents péri-atlantiques fondé sur l'isobathe -1.000 mètres et non pas sur la ligne de rivage. Trente ans avant Bullard et al. (1965), il démontre de façon indiscutable la réalité du déplacement des masses continentales à la surface de la Terre. Dès lors, Choubert privilégie totalement la « dérive des continents » comme moteur de la tectonique. Allant au-delà même de la vision de Wegener, il fait jouer ce mécanisme bien avant la formation de la Pangée triasique,

*Corresponding author: j.kornprobst@opgc.fr 
pendant toute la durée de l'ère primaire, au cours de l'érection des chaînes calédonienne et hercynienne. Bien que restant prisonnier du vocabulaire de l'époque sur les géosynclinaux, Boris Choubert décrit une tectonique fondée sur la mobilité des blocs continentaux précambriens. Curieusement, il n'applique pas ce modèle aux déformations précambriennes qu'il attribue aux effets de la rotation de la Terre sur une croûte continentale en voie de solidification. Lors de sa parution, cet article représentait un pas très important vers la compréhension de la tectonique globale et il est regrettable qu'il n'ait pas été mieux reçu par ses contemporains.

Mots clés : Wegener / dérive continentale / tectonique des plaques / orogenèse / Précambrien

\section{Foreword}

By a strange coincidence two papers were simultaneously published (Kornprobst, 2017; Letsch, 2017), both highlighting Boris Choubert's important and poorly recognized work (1935). Xavier Le Pichon was the reviewer of the paper submitted to "Geosciences" (Kornprobst, 2017); he insisted on the visionary character of Choubert's hypotheses and suggested to make the full text available again to the scientific community as it appeared in 1935 in the Revue de Géographie Physique et de Géologie Dynamique. Laurent Jolivet, the new Editor of the Bulletin de la Société Géologique de France, immediately expressed his interest towards this project; he even offered to present in the electronic version of the Bulletin, and together with the French version, an English translation of the original paper, as well as comments inspired by this text to an international audience. I went on to get in touch with about fifty colleagues, twenty-eight of whom answered favourably-sometimes enthusiastically. This number was reduced to fourteen when it became necessary to produce a contribution in due time. A synthesis of all contributions is presented below. Unfortunately, neither Choubert's original paper, nor its translation, can be shared again today, as copyright problems are not yet solved. Thus, this part of the initial project has been postponed.

\section{Jacques Kornprobst}

\section{Introduction}

What good is it to make this old piece of work more known or recognized? The title of Choubert's paper "Research on the Genesis of Palaeozoic and Precambrian Belts" did not accurately communicate the importance of its contents. In fact, that paper went almost totally unnoticed when it was published and even for a long time after. Boris Choubert interpreted the whole Palaeozoic tectonics on the basis of the mobility of Precambrian continents, which was a considerable enlargement of Alfred Wegener's theory on continental drift. Choubert's work is based on an original reconstruction of the circum-Atlantic pre-Triassic fit, much more elaborate than those of his predecessors (Wegener, 1915, Du Toit, 1926, 1937) since it was based on the -1000 meters isobaths instead of the shoreline. The accuracy of this reconstruction led its author to fully support the continental drift hypothesis and to imagine that this process is certainly not limited to the short post-Triassic history of the Earth. Boris Choubert thus appears as an unrecognized forerunner of global tectonics. The purpose of the present paper is to highlight the strengths, and sometimes even the prophetic character, of Boris Choubert's work, and also to show the few weak points that it contains due to lack of knowledge in his time of mechanisms that are today much better known.

Boris Choubert (1906-1983) was born as Boris Schuberth in St. Petersburg (Russia). He moved to Finland in 1917 for political reasons (his father was a senior officer of the Tsar's army), and came to France in 1927 to follow geological courses at the Sorbonne. He was fascinated by Wegener's "continental drift" theory (Choubert, 1981). This theory had aroused great interest but also much criticism when it was proposed more than 10 years earlier (Wegener, 1912, 1915, 1929). It is important to remember the strong support that Emile Argand gave to this innovative concept (1924). Yet, in the early thirties, this theory was highly controversial and even considered as groundless by much of the scientific community. Only Maurice Lugeon, from Switzerland, encouraged Boris Choubert to verify the arguments supporting the continental drift theory on a geological basis. In some ways, Choubert was in agreement with Pierre Termier (1924) who wrote: "To me, Wegener's theory is a beautiful dream, a dream of a great poet. One tries to reach out to it only to find oneself grasping at a cloud of steam or smoke; it is both seductive and elusive. But basically ... it cannot be said that there is nothing true in Wegener's theory..." Although he was then living in Gabon, Boris Choubert submitted a copious manuscript to the "Revue de Géographie Physique et Géologie Dynamique", then under Léon Lutaud's editorship. The title of that paper "Recherches sur la genèse des chaînes paléozoïques et antécambriennes" (Research on the Genesis of Palaeozoic and Precambrian Belts) (Choubert, 1935) did not really reflect the importance of the topics it touched on and, partly for this reason, it went almost unnoticed (Kornprobst, 2017). Only an oral presentation of his work by Emmanuel de Margerie at the French Geological Society raised a fleeting interest.

At the time of the plate tectonics revolution, from 1965 to 1968, no authors referenced Choubert's work despite how prophetic it had been - even though it was already in the list of the publications related to Wegener's theory (Vieweg \& Sohn, in Wegener, 1937, French translation). Until now, Google Scholar has only recorded 73 citations for that 80 years old paper, most of them dating back to after 1970. This has occasionally been considered as a conspiracy of silence (Gaudant, 1995; Durand-Delga, 2006) but seems to have been in fact a lack of awareness of a rather confidential work (because it was written in French) for those (especially Bullard et al., 1965) who succeeded later in convincing almost everyone of the Atlantic's opening after the Triassic. Even today, a good half of the signatories of the present text knew neither Choubert's circum-Atlantic fit, nor his general mobilistic vision. To be fair it must be noted that Choubert 
himself, in his 1935 paper, failed to mention several of his predecessors who had nevertheless brought serious arguments related to the concept of continental drift (e.g. Frank Taylor, 1910; Howard Baker, 1912, 1913a, 1913b, 1914; H. Albert Brouwer, 1921; Hans Stille, 1927; Charles Schuchert, 1928) and especially to its engine (Arthur Holmes, 1928, 1929). At that time, scientific publications did not circulate as easily as they do today!

As already mentioned above, two papers were recently published simultaneously and independently (Letsch, 2017; Kornprobst, 2017). Their purpose was to highlight Boris Choubert's work on Precambrian and Palaeozoic mountain belts and continental drift. Both emphasize the visionary character of several of Choubert's hypotheses. Without repeating the history of the concept of continental drift or suggesting that anyone infringed upon his intellectual property, it seems useful to bring forward some of the conceptual advances that Choubert's article (1935) presented to his contemporaries - while acknowledging that some of his ideas may not have resisted the test of time and new discoveries. In the following, the remarkable contributions brought by Choubert's global vision are examined throughout the text. The reader will find at the end of the article a summary of the merits and weaknesses of Choubert's paper.

\section{Review of Boris Choubert's paper: "Research on the Genesis of Palaeozoic and Precambrian Belts". The work of a young man, testifying of rare scientific maturity.}

\subsection{Introduction of the paper}

The introduction in Boris Choubert's paper is much more than an ordinary introduction, as it brings to light several crucial facts: the unavoidable reality of the circum-Atlantic continental fit (on which Choubert will not return further in the text), as well as several crucial concepts for understanding Earth's dynamics.

Boris Choubert first emphasized that "the continental drift theory, associated to Wegener's name, after experiencing some favour, seems to gather less and less supports." He does not give any more details about the quarrel that still agitated the scientific community and shows a rather positive attitude by writing: "we wondered if instead of rejecting the theory as a whole, we could not bring out the essential principle of continental drift, to which one cannot refuse the merit of being tempting since it seems to shine light on problems that old assumptions do not explain." This moderate behaviour reflects how French scientists had received Wegener's theory (Le Vigouroux, 2011; Le Vigouroux and Gohau, 2016): quasi ignorance at first related to a full rejection of German science following World War I; then moderate interest for this concept aroused by the article written in French by the Swiss geologist Elie Gagnebin (1922). The theory was met with caution but without excessive hostility, contrary to what happened in Great Britain and USA where it caused rough controversy. During a lively session of the French Geological Society (1923, April 23th), zoologists Louis Germain and Louis Fage, as well as geologist Gustave Dollfus, considered that Wegener's theory contradicted the facts (in Gaudant, 1989). They thought that "continental bridges" were the best explanation for the paleontological observations. In contrast, both Maurice Gignoux (1925) and Charles Jacob (1925) wrote that the continental drift theory brought a new light that accounts for geological facts that were difficult to explain in the context of previous tectonic interpretations. That was clearly the spirit in which Boris Choubert wrote his paper.

\subsubsection{The circum-Atlantic continental fit}

One of the most important points of Choubert's paper appears in this section: "modify the continental fit as published by Wegener", on the basis of bathymetric map data. Choubert does not give more details, but the comparison between the first two figures of his article (Fig. 1 in the present text) shows that he chose the -1000 meters isobath as a limit for continental domains, which actually corresponds to the edge of the continental shelf. It should be noted that it is the -500 fathoms isobath $(=-915$ meters $)$ that corresponds to Bullard et al.'s "best fit" (1965). Around the Atlantic, Choubert obtained an excellent fit almost everywhere - of South America and Africa as well as of North America and Europe (Fig. 1), much more convincing in illustrating continental drift than previous fits (Wegener, 1915; Du Toit and Reed, 1927) based on the shorelines. Only domains affected by postTriassic movements (especially the Caribbean) do not fit well in this reconstruction.

Choubert considered Africa and Europe as two separates entities that could be moved independently of each other. This resulted in very accurate Europe/America and Africa/America fits, but resulted in an eastwards increasing space between Africa and Europe. This was the first theoretical vision of a large pre-Mesozoic basin, later referred as "Palaeo-Tethys" (Şengör, 1979). In his 1935 paper, Choubert gave no indication of how he controlled the rotation of the continental masses (except to maintain Europe fixed). It is only as late as his 1981 article that he shared his secret: "I wrapped a globe of an imposing diameter in a veil made transparent by a layer of paraffin wax and, the projection problems being thus eliminated, I more easily verified the concordances between the various geographically distant formations." A similar technique had already been used by Schuchert (1924) to demonstrate that continental drift is unlikely to have occurred. Sam Carey (1958) proceeded in the same way 23 years after Choubert to develop his own Atlantic fit.

\subsubsection{The Atlantic Threshold}

This mountain range, located in the middle of the Atlantic (clearly visible in Fig. 1a), was discovered in 1850 by captain Matthew Fontaine Maury during the laying of a telegraph cable between Europe and America. Today, it is called the "MidAtlantic Ridge", a term Taylor was already using in 1910. This large ridge is several thousand meters higher than the surrounding abyssal plains and includes Iceland (that Choubert inadvertently called Ireland), "a huge, still active volcanic edifice, (which) is the culminating point of a ridge that had to form during the continents' separation." Choubert felt the important role of the Atlantic threshold in continental drift as he wrote that it was "the witness to the huge break that occurred between the two continents before their final 

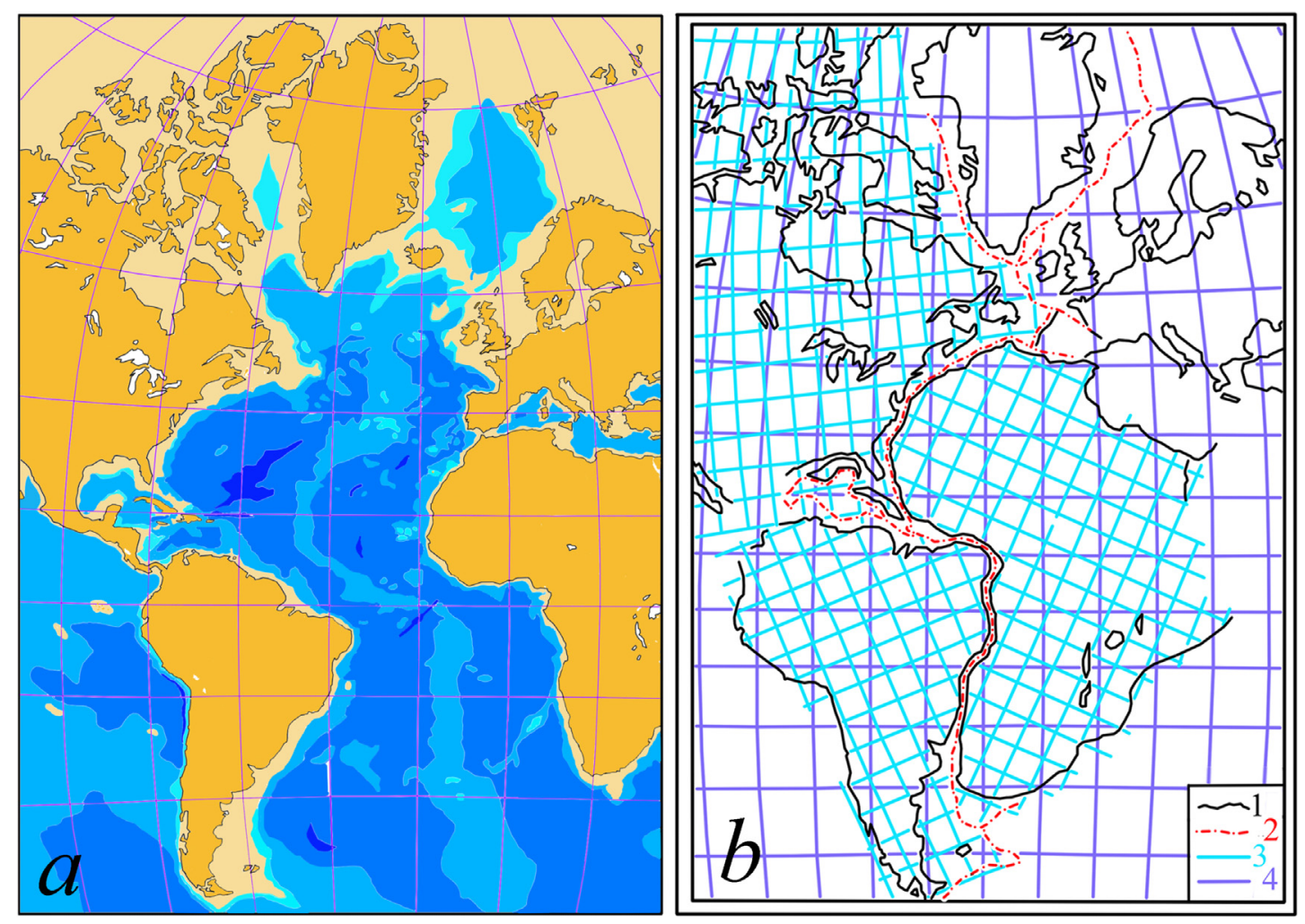

Fig. 1. Comparison of Fig. 1 and Fig. 2 of Boris Choubert's paper (1935). a - Bathymetric map of the Atlantic Ocean (redrawn after Choubert, 1935). Light beige: from 0 to $-1.000 \mathrm{~m}$; light blue: from -1.000 to $-2.000 \mathrm{~m}$.; medium-light blue: from -2.000 to $-4.000 \mathrm{~m}$.; medium-dark blue: from -4.000 to $-6.000 \mathrm{~m}$; dark blue: below $-6.000 \mathrm{~m}$; b - Fit of the continents on the basis of the bathymetric map (redrawn after Choubert, 1935).

separation... It seems to have kept its primitive position, while the continents have moved away in opposite directions", which corresponds rigorously to the working of the Mid-Atlantic ridge as it is currently observed. However, Choubert partly misunderstood the actual role of the threshold, due to the lack of knowledge in his time of the constitution of the ocean floor and its ridges. He considered it as solidified "sima" (for silica + magnesia, now upper mantle) together with vestiges of "sial" (for silica + alumina), i.e. remnants of continental crust left behind as the continents separated, an erroneous view already suggested by Argand (1924). Indeed, according to the concepts of the time, the basalts that are now known to form most of the oceanic ridges could be considered as coming directly from the "sima". However, we now know that such "sial" remains are totally lacking along the Mid-Atlantic Ridge.

\subsubsection{Continuity of geological structures on both sides of the Atlantic}

Boris Choubert made a list (p. 8) of the main geological connections between Europe and North America on one hand and Africa and South America on the other hand. Wegener (1915), Du Toit (1926) and Maack (1934) had previously made similar comparisons. But the document that came with Choubert's paper (Plate A) is remarkably accurate compared to previous sketches. It is not possible to attach this map to the present paper because it is protected by copyright. It has however been reproduced in a reduced size by Şengör (2014), by Letsch (2017) and more recently by Meinhold and Şengör (2018).

\subsubsection{Iberian Peninsula rotation}

Boris Choubert wrote: "The topography shows that the Aquitaine Basin is the natural extension of this Gulf (of Biscay) and that it represents a break whose enlargement is a result of a rotation of the Iberian Peninsula during the separation of the continents." This rotation is one of the keys to understand the Hercynian Belt (see below) but, although it was already suspected by Argand (1924), it took several decades before it was taken into consideration by other geologists (e.g. Sibuet, 1974).

\subsubsection{Intratelluric currents}

It is in a footnote to the introduction that Boris Choubert hinted at intratelluric motions that, according to Pierre Dives (1933), could animate the "sima". He briefly returned to this point in the conclusion, thus trying to answer one of the main criticisms towards continental drift: the lack of a credible engine to move continental masses. "Thus, the movement which immediately followed the last separation of the continents and dragged Africa eastwards could be explained by the existence of a W-E current within the sima". Curiously, Choubert was completely ignorant of Arthur Holmes' earlier 
work $(1928,1929)$, which described with some accuracy the role of convective currents in the mantle (sima) related to the dissipation of the heat of Earth's radioactivity. Of course, in 1935, Choubert could not have known Holmes' further work (1944), which returned more accurately to this point.

At the end of this introduction, Choubert drew its consequences and defined what he considered as the main mechanism of the orogenesis.

\subsubsection{Mobility of the Precambrian Continents}

The distribution in time and space of the Palaeozoic belts led Boris Choubert to explain them "by the relative play of the three continental masses which have completely folded the Mediterranean basin of the Palaeozoic times thanks to their multiple changes in position." Choubert added this crucial sentence: "Indeed, it makes little sense to admit, as Wegener did, that before the last separation of the continents that placed them in their current position, Pangea could have remained immutable throughout the primary era." This is a considerable advance in the continental drift concept, which Choubert considered to have played a major role not only during the Alpine orogeny, but also during the whole of the Palaeozoic.

\subsubsection{The primitive Precambrian block}

Boris Choubert was struck "by the similarities of the outlines of the Precambrian masses (Laurentian, Baltic and Gondwanian shields). This necessarily leads to think that these three masses once formed one single block." He thus came to the notion of a primitive Pangea that would have fragmented before the beginning of the Palaeozoic, just as Pangea broke up at the beginning of the Triassic. He continues: "...the direction of the Precambrian folds shows a remarkable continuity. It is obvious that not only do these folds extend perfectly from one shield to another, but they all tend to meet at a point located north of Scandinavia... This is most likely the first folding of Earth's sialic envelop." Regarding that last point it must be admitted that Boris Choubert probably let himself get carried away by his own enthusiasm.

\subsection{The "Antecambrian"}

Boris Choubert devoted 11 pages to this long period of Earth's history: Antecambrian. It must be first noted that this term is obsolete since it is now customary to use the word Precambrian, instead of Antecambrian, for sedimentary, metamorphic and plutonic rocks older than the Cambrian fossiliferous layers. Even Choubert himself sometimes used Precambrian in his paper. It is also necessary to recall that, in 1935, geochronology based on the radiometric determination of ages was still in its infancy. As a result, considering the lack of fossils, chronological relationships between various Precambrian units were based on geometrical and geological criteria (such as degree of deformation and metamorphism as well as major unconformities) that were not always easy to elucidate and correlate. Furthermore, highly metamorphosed and folded rocks, associated with various kinds of granitoïds and covered by less deformed sedimentary formations, were sometimes erroneously considered to be Precambrian. It is now known that this attribution was incorrect in a large number of cases, as for example in the Armorican Massif, the French Massif Central and the Pyrenees (e.g. Pin and Vielzeuf, 1983). The assignment of Mauritanides to the Precambrian now appears to be incorrect (Sougy, 1962), which significantly changes the Gondwana outlines. Boris Choubert acknowledged it: "Our current knowledge of the Antecambrian is very uneven." This knowledge has been much furthered today and that is why this part of Choubert's article now seems rather outdated. The geology of Precambrian shields as described by Choubert is quite different from what we know today.

\subsubsection{Outlines of "Antecambrian" Geology}

Boris Choubert described the geological units considered to belong to the Precambrian from the Baltic, Laurentian and Gondwanian continents. From the literature, he recorded the main tectonic directions of these units, which actually represents a large part of his work. He also emphasized "the considerable number of geological cycles that preceded the Palaeozoic orogeneses..." The latter were "based on the existence of unconformities that separate the different geological units and on the intrusions of the eruptive massifs that cross them." It is somewhat difficult to read Choubert today because there are often rock units and tectonic phases whose names are obsolete or little used (Ladogian, Botnian, Hoglandian in the Baltic shield, for example). It should also be noted that "Archean" was then used in a broader sense than today, including a large number of rock units currently considered as "Proterozoic". The Gondwanian continent was described in more detail than the other two, especially the west-African area, which Choubert knew well from having personally worked on it. Nevertheless, in the early 1930s, knowledge was quite limited on these large and almost inaccessible areas that were chiefly known through military expedition reports (cf. Porch, 1984). Boris Choubert conducted an excellent study of this colonial literature, synthesizing the observations with an elegant geological map (part of his Plate A) that suggests a fairly complex tectonic structure for the whole area. He described (see details in Letsch, 2017) several mountain belts (from Upper Proterozoic - or Pan-African - to Upper Palaeozoic) that fringe the West African craton (e.g. Dahomeyides, Rockelids and Mauritanides), most of which were only identified much later (e.g. Sougy, 1962; Allen, 1969).

\subsubsection{The Precambrian continent}

As this was announced in the introduction section, Boris Choubert developed the idea of a primitive Precambrian continent. It was based on an assemblage of the continental masses that significantly differs from those later established on the basis of paleomagnetic data: "the Greater Gondwana", "Rodinia" or "Pannotia" (e.g. Dalziel, 1991, 1997; Scotese, 2004). The position of the Indian subcontinent, in particular, is identical to its current position, which leads to caution when considering Choubert's "continuity of the tectonic lines" from one continent to another. He wrote: "I have already said that the continental blocks, deprived of all the parts that were formed from the Palaeozoic, fit together perfectly to form a whole that can be named the Precambrian continental block." Choubert continued: "Fig. 1 of Plate I (in fact, Plate I only 
shows Fig. 3 and 4. It constitutes the Fig. 2 of the present text) shows that Antecambrian fold belts, from one continent to another, follow the same guidelines and that all tend to meet in a single point." Based on the eastwards general convexity of these guidelines, Choubert considered that "everything tends to demonstrate the interdependence of this "primitive" folding with the centrifugal force caused by the Earth's rotation." According to Choubert, "as a whole, the lines give the impression of a folding that could have affected a plastic mass during a cooling process..." Deviations from the general direction of these lines are considered as "eddies that the sialic mass forms in the neighbourhood of the equator (due) to
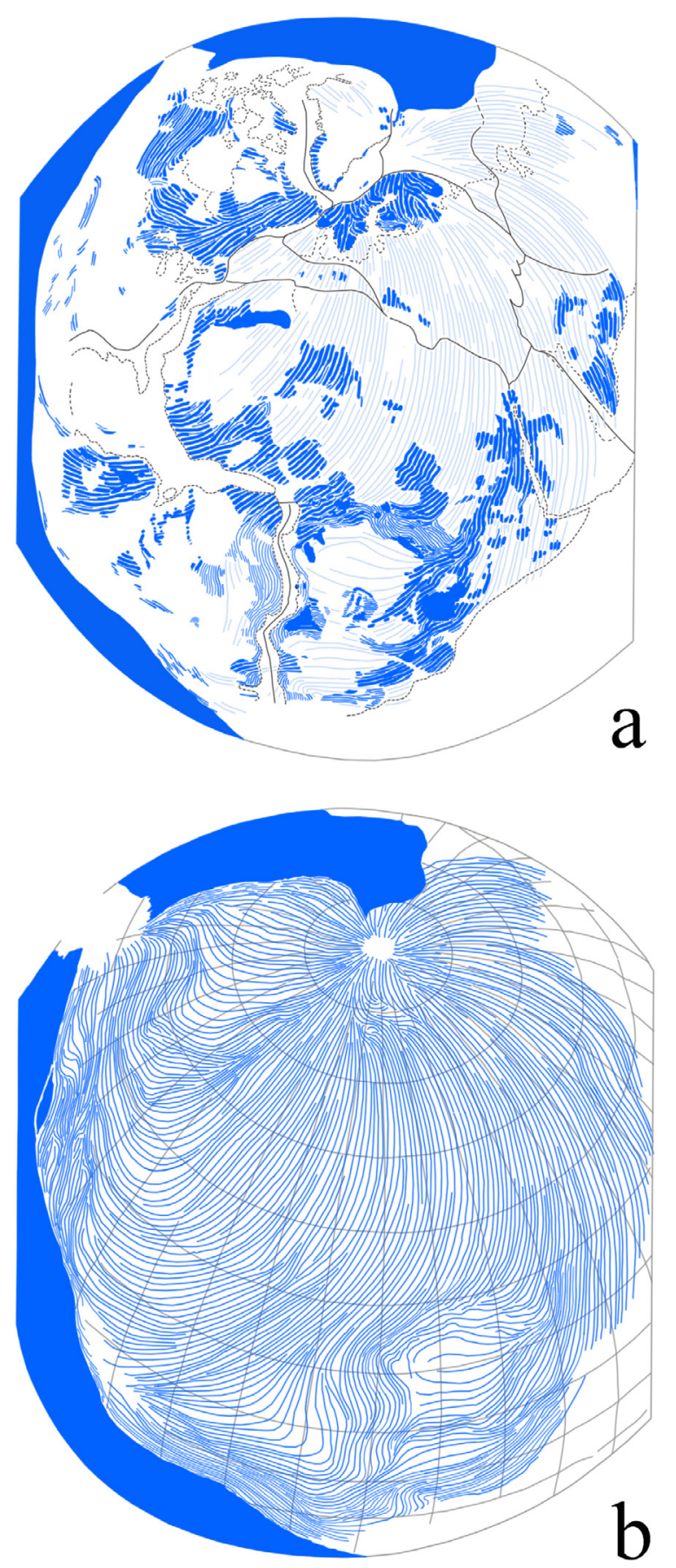

variations in rotation velocity as well as unequal solidification." Choubert stated that the multiple unconformities reported within the Precambrian units could be related to the formation of basins invaded by the sea and filled by the erosion products of the primitive mountains, in turn folded, metamorphosed and intruded by granitoïds. Choubert added: "The continuity of the motion that affected the sialic mass (explains) that the folds show about the same direction throughout the Antecambrian."

According to Choubert, "there is an essential difference between the formation of these folds and that of the Palaeozoic mountain belts: the first have a universal character while the others, whatever their scale, are only accidents." This assumption of an essential difference between Precambrian and Phanerozoic tectonics had already been suggested before Choubert by Eduard Suess (1885-1909), and afterwards were revived by Kevin Burke and John Dewey (1973). However, it is generally no longer supported by present-day geologists although there is petrological evidence of a change in Earth's thermal regime, at least at the Archean/Proterozoic boundary (Andrault et al., 2018). Indeed, Choubert seemed to consider that Earth's geological history happened in two separate stages:

- formation of a Precambrian continental crust which was deformed following a global coherent pattern linked to the rotation of the Earth;

- fragmentation of this primitive Pangea (currently known as Pannotia) in several secondary blocks at the end of the Precambrian or during the early Palaeozoic, which, by their relative motions, caused mountain building by closure of the inter-block spaces.

Choubert thought that the process of continental drift only started with the Palaeozoic. This systematic vision led him to underestimate facts that he had himself highlighted. Indeed, in several regions and especially in the Central African area (see Fig. 3, drawn from Choubert's Plate A), structural trends are clearly unconformable and even orthogonal, belonging to two different belts now known as the E-W and N-S Neoproterozoic belts, in Central and Eastern Africa respectively. Thus, Choubert drew different Precambrian orogenic structures,

Fig. 2. Explanation of Plate I (redrawn from Choubert, 1935). "Reconstruction of the Precambrian Continental Blocks. This construction highlights the continuity of Precambrian fold directions and their tendency to join at a single point". Fig. 2a shows the fold directions in the Precambrian shield areas (dark blue) within the circum-Atlantic continents, as perceived and drawn by Choubert (1935), and their supposed extensions (light blue) in the intermediate areas. Fig. $2 b$ shows a coherent pattern, as imagined by Choubert converging to a point north of Scandinavia, and suggested to be related to a general westward drift of the continents caused by the eastward rotation of the Earth, causing deformation within the sialic crust. This apparently assumed that all Precambrian orogenies could be broadly correlated, irrespective of age, and had originated from the same process, linked to the rotation of the globe rather than to movements of individual plates and collisions between those. It also assumed that all of the continents remained fixed in the same position throughout the Precambrian, and did not start to drift apart until the early Palaeozoic. 


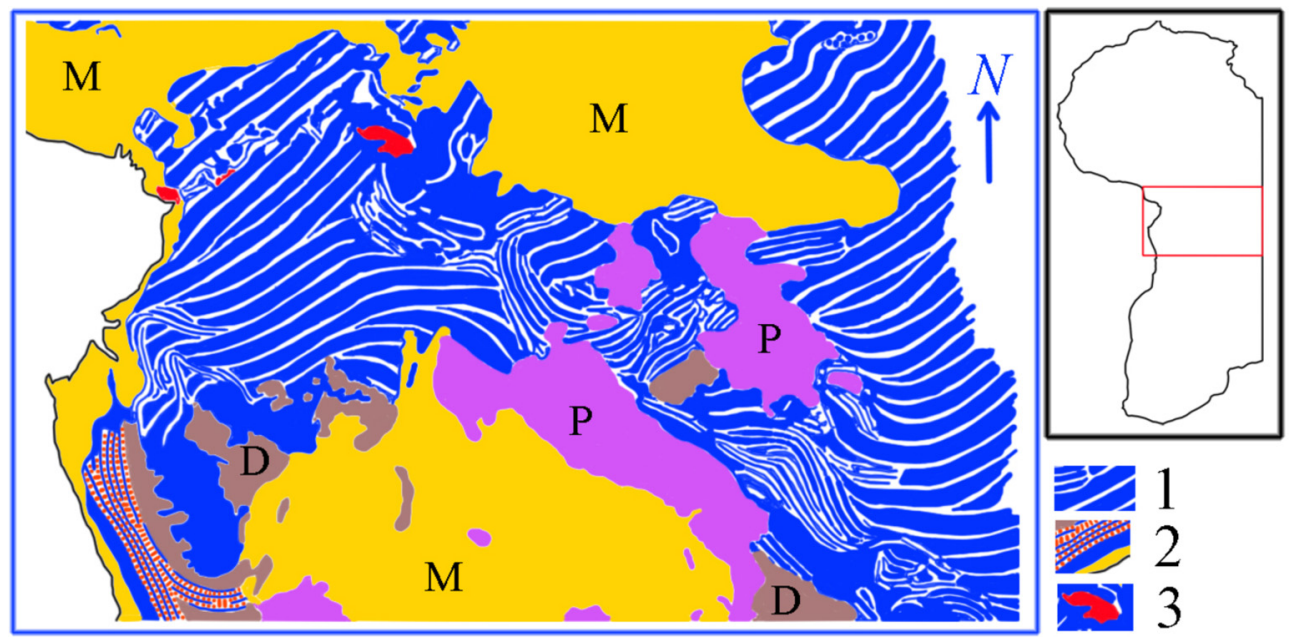

Fig. 3. Geometrical relationships between the tectonic directions of Precambrian belts in the Central Africa area (redrawn from Choubert, 1935, Plate A). Africa is in its orientation before the Atlantic opening. Note the almost orthogonal structures in the centre of the sketch, which seem to be the result of a belt having been squeezed between two former Precambrian blocks, rather than from a swirl linked to Earth's rotation. 1- Precambrian belt structural directions. 2 - Belt of unknown age. 3 - Post-Hercynian volcanic rocks (red). D: Devonian; P: Permian; M: Mesozoic.

but he did not make any connection with what he described further in his paper for the Palaeozoic belts around the Laurentian and Baltic blocks for example. Yet he used the word "belt" (chaînes) to describe these structures in the caption of Plate A. Why did he support this difference between Palaeozoic and Precambrian? It is difficult to say, unless we suppose that he wanted to give a specific role to the whole Precambrian period in Earth's cooling history and formation of continental crust. He was probably not completely wrong on this point, but he pushed his conviction a little too far, viewing these structural deviations as the result of swirls, which were especially prevalent near the equator where the Earth's rotational speed is the fastest.

However, the last sentence of the section devoted to the Precambrian is very important: "The breaks that occurred at the end of the Antecambrian individualized three masses early on in the Cambrian, i.e. Laurentia, Gondwana and the Asian-Baltic continent" (it should be noted that there Choubert neglected the late Palaeozoic Uralian collision between Baltica and Asia even though it happened in his motherland). It is obvious that Boris Choubert had perfectly understood the process at work at the beginning of the Palaeozoic, and the fundamental mechanism of the Caledonian and Variscan orogenies - the fragmentation of a predecessor of Pangea and the individualization of the three large continental masses (Laurentia, Gondwana and Baltica), which were to play a major part in the building of mountain belts during the Palaeozoic era. Choubert considered continental drift to have played a major role during Palaeozoic times whereas, curiously enough, he did not consider this mechanism to be the cause of the folding that affected the sialic crust during the Precambrian.

\subsection{Cambrian, Ordovician and Gothlandian: The Caledonian Belt}

When his 1935 paper was published, Boris Choubert was not yet thirty years old and only had a bibliographic knowledge of Palaeozoic mountain chains. At that time, his field experience was confined to Gabon's Precambrian shield, which he worked on in 1933 . He was very far from having the knowledge of the great masters of the time, such as Charles Barrois, André Demay and a few others, who knew in detail the Caledono-Variscan units of Europe. However, Choubert actually engaged in an experiment that did not require a deep knowledge of Palaeozoic chains. He limited himself to reconstructing the circum-Atlantic continental blocks on a bathymetric base, and to observing what became of the Palaeozoic domains in this new configuration. This operation showed him that the Palaeozoic belts separate two continental masses in the North, Laurentia and Baltica, and the Gondwanian continental mass in the South. He concluded that "it is between these three masses, already frozen before the Cambrian, that the Palaeozoic mountain chains are compressed and that it is the relative motion of the three continental masses that have folded... the geological units of the primary era." Choubert continued: "At the beginning of the Devonian, the Laurentian and Scandinavian (i.e., Baltica) shields are welded together by the Caledonian Belt. From that time on, there are only two large continental masses: the North-Atlantic continent (i.e., Laurussia) and Gondwana." $\mathrm{He}$ also specified that "if the folds of the Palaeozoic belts were unfolded, the continental masses fixed before the Cambrian would be separated by much larger spaces and their reciprocal locations would be different."

Having already stated that "the three continental masses once formed one single block", Choubert therefore successively considered the fragmentation into three pieces of the great Precambrian continent, then the divergence of those three blocks during the Neoproterozoic, and finally their convergence during the Palaeozoic. More than 80 years after Choubert's publication, his conclusions are broadly consistent with modern interpretations.

"At the time of the transgression that marks the beginning of Palaeozoic times, the three large continental masses - fragments of the original sialic block - are already independent." Thus begins Choubert's chapter devoted to the lower Palaeozoic. He thus suggested, at the end of Precambrian, a fragmentation of the primitive Pangea, similar to what 

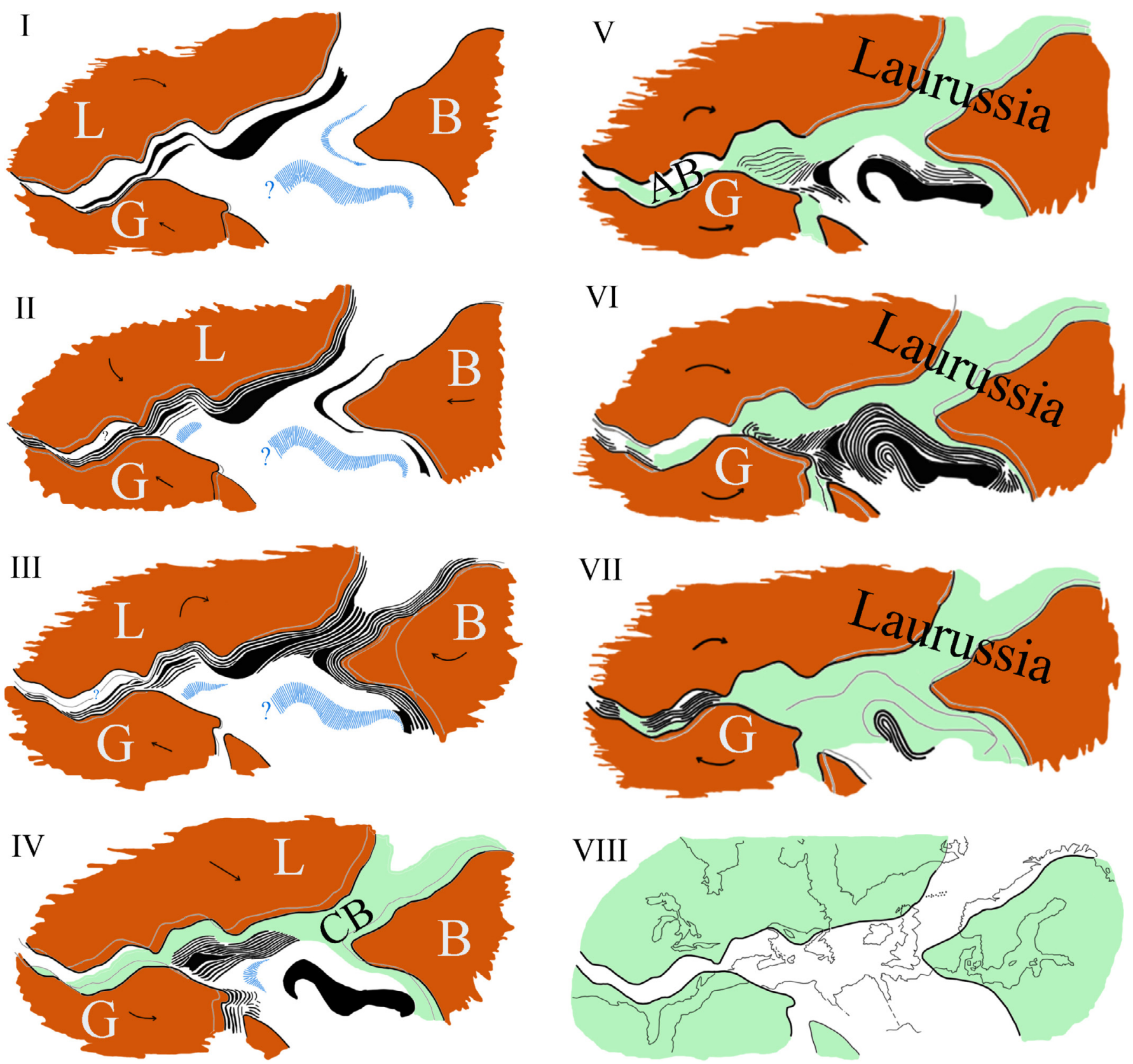

Fig. 4. Genesis of the Palaeozoic Belts (redrawn from Fig. 3 in Choubert (1935). Prehercynian Orogeneses: I.- Upper Cambrian and Lower Ordovician. II.- Upper Ordovician, Laurentian Continent (Taconic Belt). Middle and upper Ordovician, Baltic Continent. III - Upper Gothlandian (Caledonian Belt). Post-Downton, Laurentian Continent. Ante and post-Downton, Baltic Continent. IV.- Upper Devonian (Acadian Belt). Hercynian Orogeneses: V.- Upper Dinantian (Sudete Phase). VI. - Upper Westphalian (Main Hercynian Phase). VII. - Stephano-Permian (Appalachian Phase). VIII. - Sketch to refer to the main map. Grey lines: boundaries of the Precambrian continental masses (Situation at the beginning of the advance). Black regular lines: boundaries of the Precambrian continental masses (New situation, at the end of each advance). Thin regular lines: boundaries of the Precambrian continental masses that are not possible to specify today. Pale blue hatching: emerging geanticlines, or Precambrian sialic thresholds. Black: already formed geanticlines. Pale green: previously formed belts. (Sketches IV-V-VI-VII). Brown: Precambrian continental masses. Dashed: geographical outlines. (VIII.) It is obviously impossible to specify the amplitude of the displacements of the continental masses. We simply attempted to represent them by indicating the new position of continental masses with respect to their previous situation. Thus, the new position of a continental mass becomes the previous position in the following sketch. L: Laurentia; B: Baltica; G: Gondwana; CB: Caledonian Belt; AB: Acadian Belt 
happened much later for the post-Triassic Pangea. He compared the way these blocks separated to that of the circum-Atlantic continents after the Triassic: "a set of shoals, that now form the old cores of the primary chains in Europe as well as in the Atlantic part of North America ... are the remains left by the continents during their separation. They represent either witnesses to the primitive position, similar to the Atlantic threshold, or island garlands." The former interpretation nowadays seems rather erroneous. Indeed, the true Atlantic threshold - or mid-Atlantic ridge - has no continental sialic crust. In addition, geochronology has shown that the "old cores" of Palaeozoic chains often correspond to early metamorphic and igneous phases of the Palaeozoic orogenies (e.g. Pin and Vielzeuf, 1983). On the other hand, the "Island Garlands" are reminiscent of "island arcs", nowadays related to subduction, and hence a much better model for the Cadomian, Avalonian, Armorican and Saxothuringian periGondwanian terranes Choubert referred to as "shoals".

In his conception of orogenesis, Choubert remained firmly attached to notions that are no longer accepted, such as: metamorphic culmination leading to "complete granitization"; or the importance given to "geosynclines", i.e. to relatively narrow mobile zones in between fixed and rigid continental areas (Haug, 1907-1911; Aubouin, 1961, 1965). In this concept, geosynclines were subdivided into partially and temporarily emerged geanticline ridges, parallel to the mobile zone, and in secondary geosynclinal depressions alternating with the geanticlines. Throughout the geosynclinal evolution, motions were supposed to be strictly vertical, with rising geanticlines and subsiding geosynclines. Such behaviour is totally opposed to Choubert's real idea that horizontal translations played a major role. It is obviously possible to consider in part the geosynclines as the trenches associated with subduction zones, in which accretionary prisms develop; and to consider in part geanticlines as "volcanic island arcs" which are generally located behind the subduction zones. But it must be kept in mind that geodynamic concepts developed since the 1960 s were completely unknown to Boris Choubert.

The constitution of the sedimentary series, the evolution of their bathymetric characteristics and the paleontological links between the different basins are interpreted as the consequences of the motions of the continental blocks. It is remarkable that Choubert was able to find paleontological arguments to distinguish between Cambrian American and European faunas; these faunas merged only after the convergence of the plates during the Ordovician and their collision during the Silurian, and until Permian in the Ural. He found evidence for this in old literature (perhaps already mentionned in Walcott, 1891) about Finnmark, northern Norway, even though the facts that he mentionned were only confirmed much later (e.g. Holtedahl, 1960; Harper et al., 2008).

The movements of the Precambrian blocks are shown on Fig. 4 (redrawn from Choubert's Fig. 3), which is "probably the first plate reconstruction for the Palaeozoic" (Letsch, 2017). Nevertheless, this series of maps only shows very small plate movements, outlined with arrows and thin grey continental contours, in spite of Choubert describing various continental movements in the accompanying text, sometimes in great detail. In fact, it is arduous to evaluate the range of translation that affected the continental blocks, as it is for the actual rotation angles of the continents. Boris Choubert did not ask himself too many questions but he wrote further in the text (p. 30): "Everything happens as if the slow and gradual convergence of the two continental masses, by decreasing the distance between them, dug a trench in front of each of them." He was not yet imagining subduction, but understood that there was a problem of space!

According to the custom of the time, Choubert used the name "Gothlandian" to refer to what is now called Silurian; he also used "Silurian" in the now obsolete sense of "Ordovician + Gothlandian", which is a bit confusing for modern readers. He seems to have identified the Cadomian and Assyntic orogenic phases, without having named them, in connection with "a South-Eastwards advance of Laurentia". He specified that the continuation of this motion resulted in the erection of the Taconic belt at the end of the Ordovician.

Choubert emphasized that, during this period, Laurentia pivoted as it moved forward, and that "the Baltic shield underwent two successive advance to the west", which resulted in a diachronous evolution of the Caledonian Belt that was built at the end of the "Gothlandian" (i.e. Silurian in modern sense). It is also remarkable that Choubert was able to point out the close correlation between the Caledonian and Acadian orogenic events that affected northern Europe (including Scandian and Svalbardian events of the Caledonian Orogeny), Greenland and North America, thus proving the existence of the Iapetus Ocean (Precambrian Sea) during Neoproterozoic times, well before the publications of Tuzo Wilson (1966) and others some thirty years later.

\subsection{Devonian and Carboniferous: the Hercynian (or Variscan) Orogeny}

"At the beginning of the Devonian, the Laurentian and Scandinavian shields were welded together by the Caledonian Belt. From this time on, there are two large continental masses: the North Atlantic Continent (now called Laurussia) and Gondwana." Thus begins Boris Choubert's chapter on this period that was crucial for the structuring of Western Europe. In his mind, the major element of Devonian geology was the deposit of the "Old Red Sandstones" whose considerable thickness contributed to Great Britain's "subsidence" (an unfortunate slip of the pen led him to write, p. 30, that "the Devonian is lacking in the British Islands"; he naturally meant to talk about the Middle Devonian). According to Choubert, continental motions occurred all along the Devonian but only resulted in few deformations; "this is because of the direction of the translation which was parallel to the edge of the NorthAtlantic continent." These movements were however the cause of the Acadian deformations. But, he wrote, "the main movements of the Hercynian orogeny occurred in the Carboniferous." This phase is known as the "Bretonian Phase" (Stille, 1927; Faure et al., 2017). Choubert thus greatly minimized the tectonic, metamorphic and plutonic events that actually occurred during the Devonian, following processes that had already started in the Silurian in connection with Gondwana's northward motion. Indeed, when it comes to the Armorican, Arverne and Bohemian "cores", for example, which were at that time thought to be of Precambrian origin, nothing could let him imagine - by lack of geochronological 


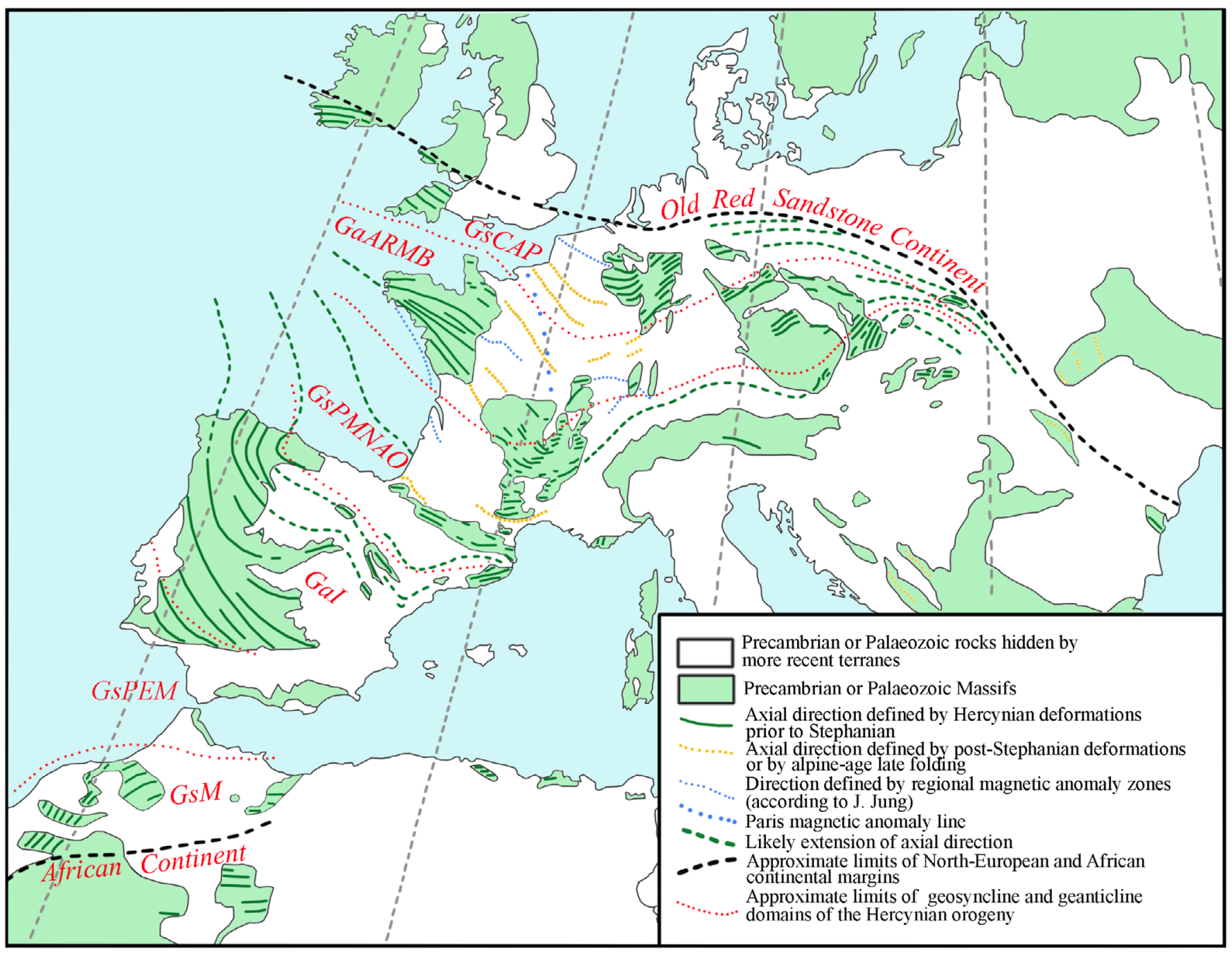

Fig. 5. Structural map of the Hercynian Belt. Redrawn from Demay (1934a, 1934b). GsCAP: Cornwall-Ardennes-Poland Geosyncline; GaARMB: Armorican-Morvan Roannais-Bohemian Geanticline; GsPMNAO: Pyrenees-Montagne Noire-AlpesOrientales Geosyncline; GaI: Iberian Geanticline; GsPEM: Portugal-Southern Spain Geosyncline; GsM: Morocco Geosyncline

data - that these regions may have had a very important early Palaeozoic history.

However, Choubert's paper is still remarkable in its rather modern interpretation of the Hercynian Belt. To show the pioneering character of his vision, it seems appropriate to make a comparison between Choubert's model and (1) on the one hand the knowledge that we had in France on the Hercynian Belt in 1934, (2) on the other hand the current interpretations.

\subsubsection{The classical interpretation of the Variscan belt in the early 30 's}

This interpretation was mainly based on two papers by André Demay (1934). Indeed, very few geologists had tried to interpret the Hercynian belt on the basis of continental drift; the work of Franz Kossmat (1927), almost completely unnoticed, is an exception that should be emphasized. For Demay, as for most of his contemporaries, the Hercynian Belt was the result of the evolution of a geosyncline. In his first article (1934a), Demay drew five maps of Europe describing the paleogeogra- phy, from Cambrian to Permian, which allowed him to illustrate the geosynclinal evolution of the "mobile zone". The geosyncline is wedged in between the two rigid claws of northern Europe and Africa. It is subdivided into several parallel zones that are, from north to south (Fig. 5):

- the Cornwall, Ardennes and Poland geosynclines;

- the Armorican, Morvan-Roannais and Bohemian geanticline;

- the geosyncline of the Pyrenees, "Montagne Noire" and Eastern Alps;

- the Iberian geanticline;

- the Portuguese and Southern Spain geosyncline and finally,

- the Moroccan geosyncline.

In his second paper (1934b), André Demay described the structure of the belt and the Hercynian orogenic evolution. His purpose was to draw the "axial plane" of this mountain range and to highlight the continuity of the structural zones. 

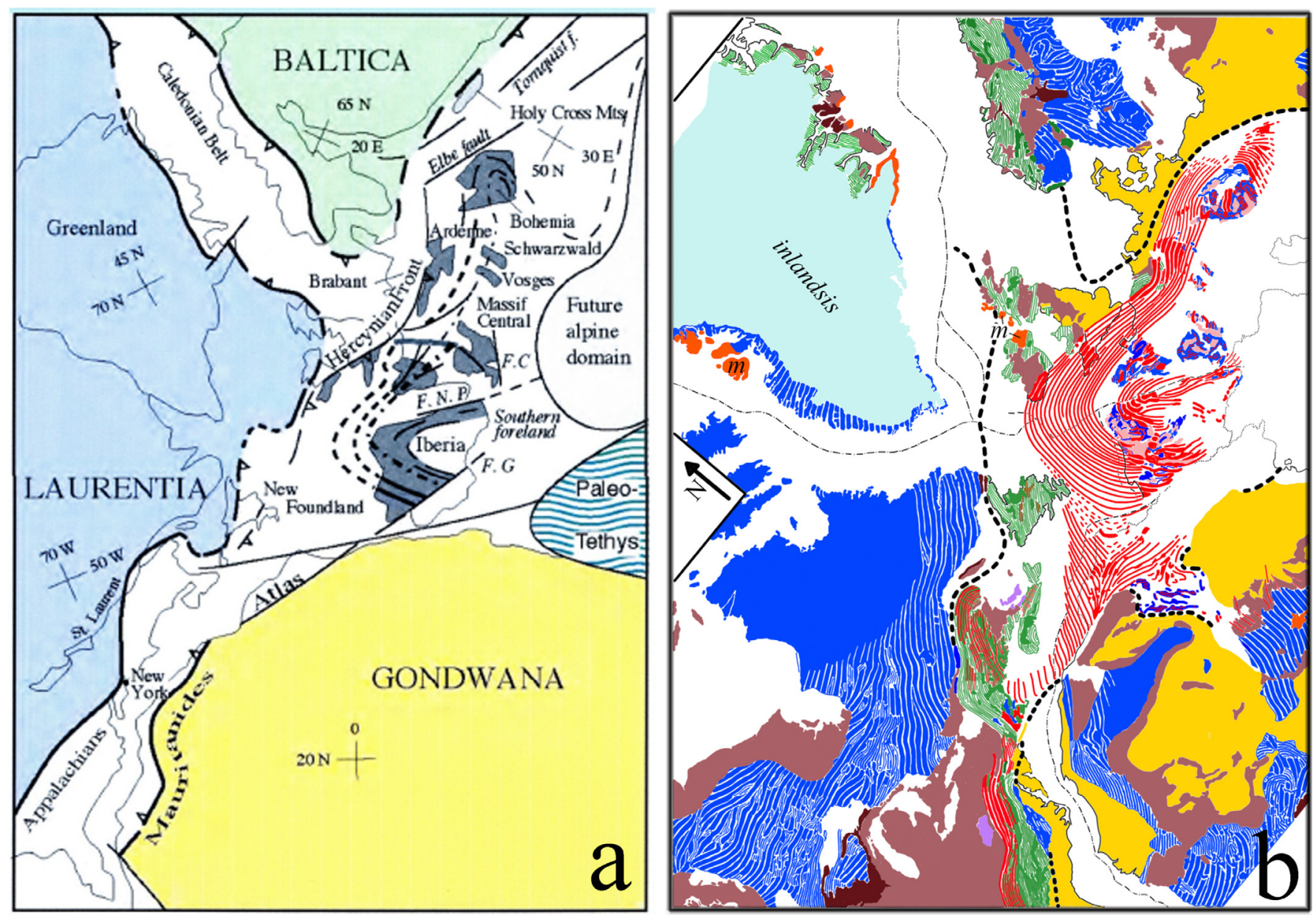

Fig. 6. The Palaeozoic Belts prior to the opening of the Atlantic: according to a) Michel Faure (2013); b) Boris Choubert (1935). Note the very similar structural situation of the Hercynian belt (slate gray in the left, red on the right) as being in both sketches compressed in between BalticaLaurentia on the one hand and Gondwana on the other hand. Fig. 2b: Deep blue: Precambrian belts; deep brown: unfolded Precambrian units; light brown: unfolded Palaeozoic units; violine: Permian rocks; yellow: post-Hercynian unfolded rocks; green: Caledonian and Taconic Belts; striped (green and red): Acadian belt; red: Hercynian belt. Thick black dashed lines: supposed outlines of the Precambrian continental blocks.

Stratigraphic (isopic zones) and metamorphic zonation are compared with the structural zonation; it appeared that all these zones are superimposable, and that stratigraphic data are therefore directly usable in the discussion of the tectonic structure.

Demay illustrated his interpretation with a sketch of the "Axial plane of the Hercynian chain" (Fig. 5). He drew the axial directions of the ante-Stephanian deformations, those of the Stephanian deformations, as well as the "probable connections or extensions of the axial directions" in the regions without outcrops. The zone (or arc) that gives the chain its general look is the one that joined the Armorican Massif (in Bretagne) and the French Massif Central with Bohemia via the Variscan "V". In this interpretation, the structural zones are roughly parallel to each other and extend westward, especially in the Bay of Biscay. Demay's map shows no significant "virgation" (or orocline), except for that along the "Tornquist line" (the suture along the Baltic shield). Demay rejected the possibility of an Ibero-Armorican arc and did not suggest any connection between Spain and Morocco. The question of the "direction of orogenic forces and apparent motions during the main orogenic phases", as well as that of horizontal motions in general, was referred to in a later paper that never got published. An important point of Demay's model is its fixist aspect; the continental drift hypothesis was not considered at all. It must be remembered, however, that Demay has described horizontal displacements in the French Massif Central, and was the first in France to link ductile deformation and metamorphism.

\subsubsection{Modern interpretations of the Variscan Belt}

The modern interpretations are resolutely mobilistic, according to the plate tectonics model. Figure 6a (Faure, 2013) shows the distribution of the Palaeozoic belts after the last collision and before the opening of the Atlantic. The continents that converged during the Palaeozoic to form Pangea are Laurentia, Baltica, Siberia and Gondwana. At first, the collision between Laurentia and Baltica ( + Avalonia) generated the Caledonian belt; the whole of Laurentia, Baltica and Avalonia, to which the Caledonides are associated, thereby formed the Laurussian supercontinent. The convergence 
Ediacarian

$620-540(\mathrm{Ma})$

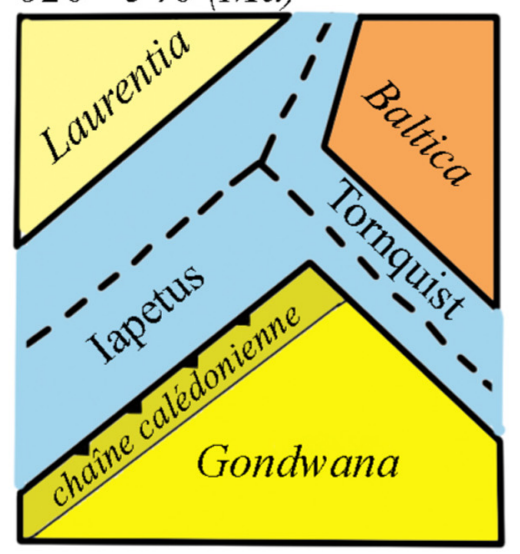

Middle-upper Ordovician

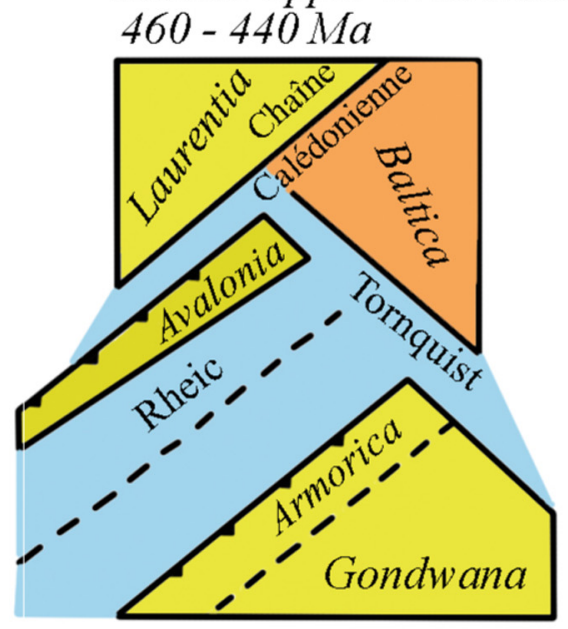

Lower Cambrian

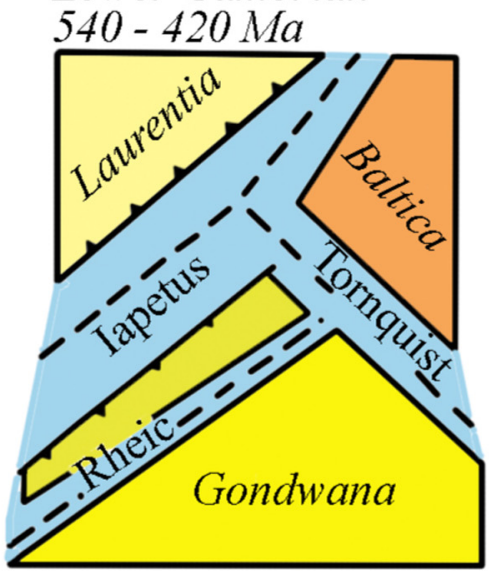

Silurian

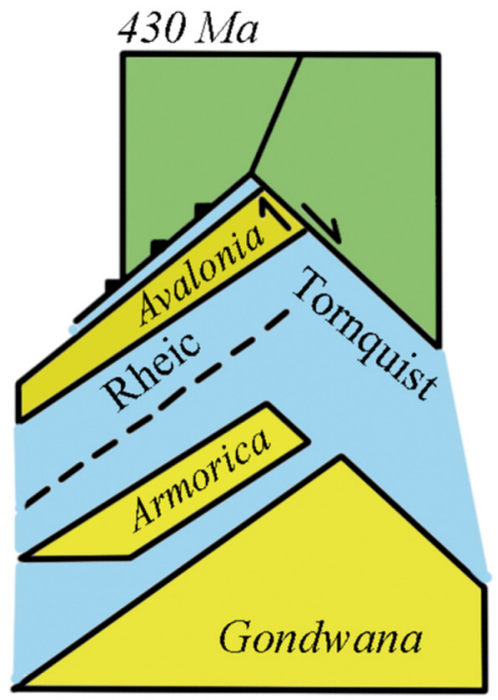

Lower Carboniferous

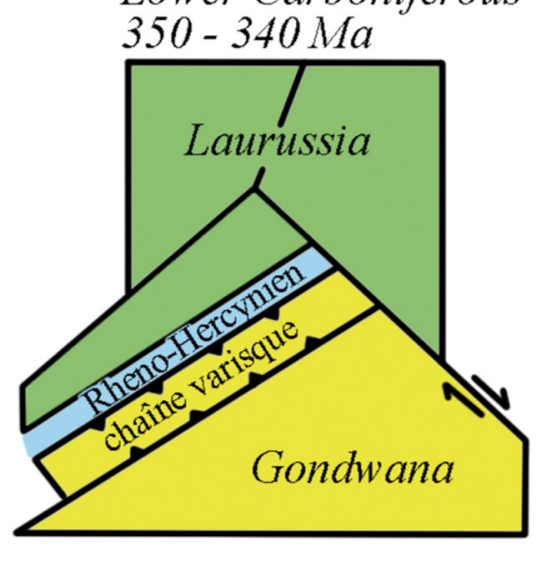

Lower Ordovician 480 - $460 \mathrm{Ma}$

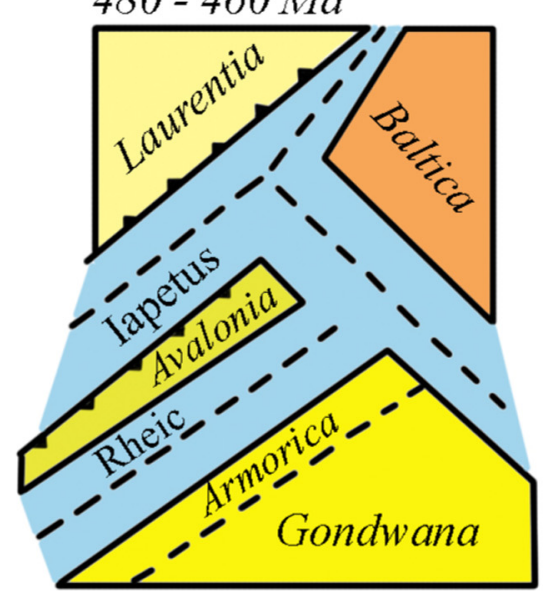

Lower Devonian

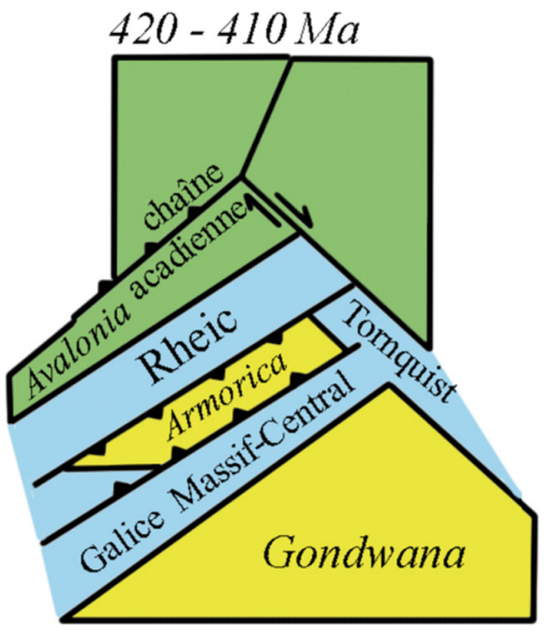

Upper Devonian

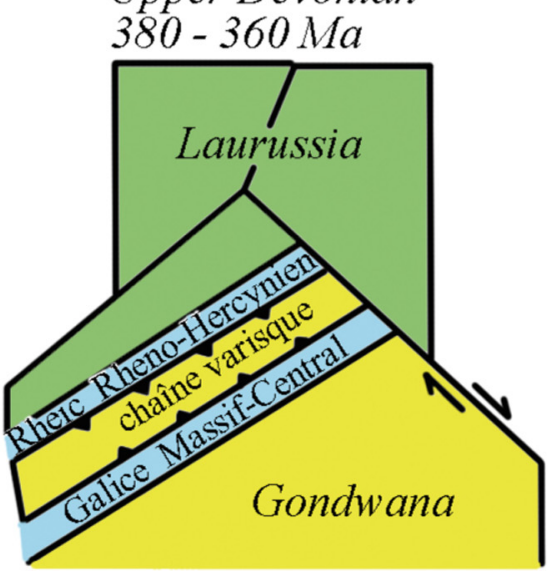

Upper Carboniferous

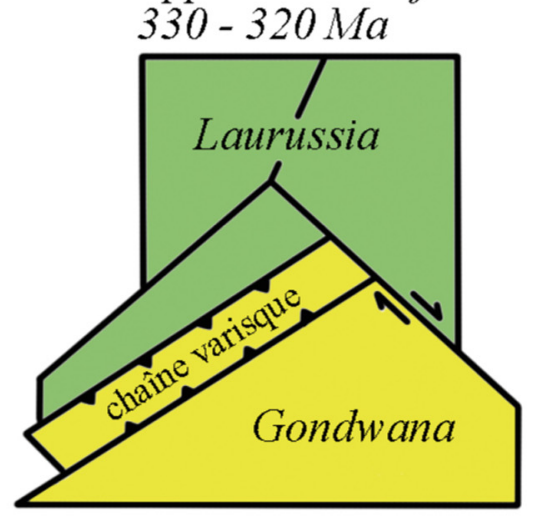

Fig. 7. Geometry and plate kinematics during the Palaeozoic; redrawn from Ballèvre et al., 2013.

between Laurussia and Gondwana, during the Devonian and Carboniferous, resulted in the formation of the Variscan belt in Europe, and of the contemporaneous belts in North America (Appalachian Belt) and West Africa (in Morocco and
Mauritania). Figure 7 (Ballèvre et al., 2013) details this collision that involved several domains detached from the north Gondwanian margin (peri-Gondwanian terranes), separated by small oceanic basins. The Armorican microplate was 
thus located in between the Rheic Ocean in the north, and the Galicia-Massif Central Ocean in the south.

\subsubsection{The Variscan Belt according to Boris Choubert} (1935)

The representation, as given by Choubert (Fig. 6b), of the Palaeozoic belts stuck between the three Precambrian continents, is strikingly similar to current representations. Choubert gave a surprisingly realistic picture of the Hercynian Belt, having in particular drawn the Ibero-Armorican and Bohemian oroclines. The opening of the Bay of Biscay had already been considered by Emile Argand (1924), but it was Choubert himself who gave the first arguments for the rotation of the Iberian Peninsula: the fact that the Bay is very deep, that its bottom is filled with very recent deposits extending the Aquitanian Basin, and the identity of the two margins that formed an orocline before the dismantling of the Hercynian Belt. It was not until the mid-1970s that the reality of the rotation of the Iberian Peninsula was universally accepted (e.g. Sibuet, 1974).

\subsection{The conclusions in Boris Choubert's paper}

The conclusion section in Boris Choubert's paper (1935) was not written as a normal conclusion section summarizing the paper and highlighting the main points of the text, but rather a set of additional remarks based on various observations.

Thus, the author put forward a very interesting opinion on the beginning of the opening of the Atlantic, starting in the Jurassic: "Extremely variable thickness and facies changes in series from the Jurassic and the Cretaceous in northern Africa (P. Fallot, M. Blumenthal, A. Marin) prove the constant changes in sedimentation conditions and demonstrate that the eastward sliding of the African continent took place during those times, along the southern edge of Hercynian Europe." He also based this opinion on the intrusion of "ophites" (mainly doleritic dykes) in the Pyrenees and North Africa: "The faults that preceded the separation of the continents could have occurred as soon as the end of the Triassic." He thus preceded those who would much later see the manifestation of a major thermal event $(\mathrm{CAMP}=$ Central Atlantic Magmatic Province; e.g. Bertrand et al., 1982; Bertrand, 1987; Marzoli et al., 1999; Knight et al., 2004) in these rocks, which preceded the rifting and opening of the Atlantic. He correctly noticed that "all these observations seem to show that the African Continent is still in motion." Towards the end, however, Boris Choubert made a rather surprising statement: "It is not within the competence of a geologist to investigate the ultimate causes for the separation of the continents." It may seem difficult to accept this statement, unless the term "geologist" is taken in a very limited sense, leaving geophysics aside.

\section{Boris Choubert (1935): a thoroughly modern vision of orogeny resolutely ahead of his time.}

After studying Wegener's work, Boris Choubert thought that crustal deformations are essentially linked to continental block motion on the Earth's surface, i.e. to continental drift. In order to ensure the validity of this concept, he started by checking on bathymetric bases, that the pre-Triassic fit of the circum-Atlantic continents was not an illusion. With a rather artisanal technique, he achieved a remarkable fit that was almost identical to the one that would be crafted 30 years later by Edward Bullard, Jim Everett and Gilbert Smith (1965) through the use of computer and least squares-techniques. Of course, neither of these two fits is perfect. They cannot be since the extension of continental margins accompanied the continent separation. Displacement of "tilted blocks", eruption of rift-related magmatism and deposition of thick sedimentary shelves, together preclude any hope of strictly adjusting the craton limits to their true initial configuration (Kornprobst, 2017).

Convinced of the reality of the continental drift theory, Boris Choubert then used the tectonic directions of Precambrian rocks to demonstrate the existence of a single supercontinent at the end of the Proterozoic, a continent which was similar to the pre-Triassic Pangea. According to Choubert, this very large crustal unit was fragmented during the Neoproterozoic by a mechanism identical to that of the separation of America, Africa and Europe, and the formation of the Atlantic Ocean during the Mesozoic. This initial fragmentation gave rise to three different cratons (Laurentia, Baltica, Gondwana) whose separation led to the formation of Iapetus, Rheic and Medio-European oceans containing geosynclines in which sediments were accumulated from the Cambrian to the Carboniferous. Choubert then considered the horizontal motion of the cratonic masses (without insisting on its causes) as the main engine for orogeny during the whole Palaeozoic period. Sediments deposited at the bottom of "geosynclines" and on "geanticline" ridges, were deformed by the jaws of this gigantic vice during their convergence. Choubert did not question Emile Haug's (1907-1911) vocabulary despite its obsolescence due to the fact that the essential tectonic movements were explained by horizontal translations rather than by vertical motions. However, he felt the limits of his model because he lacked space to unfold the sedimentary series. He imagined the formation of trenches (geosynclines) in front of some continents, of course still being far from thinking about the disappearance of the whole ocean floor in the depths of the Earth, by a process like subduction (in fact, he seemed to be ignorant of Otto Ampferer's "Verschluckung", 1906). He obviously could not imagine subduction since it was only in the same year that Kiyoo Wadati (1935) published his founding article. Much later, the major work of Hugo Benioff (1949) led to the interpretation of Benioff-Wadati zones in terms of lithospheric subduction (Oliver \& Isaks, 1967). Boris Choubert's vision of the orogenies of the whole Palaeozoic Era is summarized in Fig. 4, which is the first plate reconstruction for the Palaeozoic (Letsch, 2017). It is very similar to current models and, despite the progress made over the last 80 years, bears witness to the remarkable insight of its author.

Choubert thus took continental drift one large step further back in time, compared to Wegener. While Wegener was only considering the break-up and dispersal of Pangea into the continents of present-day Earth, Choubert was also considering the Palaeozoic assembly of Pangea from its various Precambrian building blocks. By explaining these Palaeozoic 
orogenies as the result of previous continental collisions, he also invoked the presence of pre-existing oceans, such as the Iapetus Sea, the predecessor of the Atlantic Ocean, where early Palaeozoic sediments had been deposited. Yet, despite this clear vision of Palaeozoic mountain building, Boris Choubert did not apply his orogenic model to Precambrian times. Instead, he preferred to attribute tectonics of this very long period to stresses developed by the Earth's rotation on a cooling sialic crust. Proposing continental drift way back in the Precambrian, with Precambrian fold belts being the roots of ancient mountain belts that had originated by earlier continental collisions, may have been too large a leap forward even for a visionary thinker like Choubert.

As it is now well known, Choubert's paper (1935) went almost totally unnoticed at the time of its publication. The author's contemporaries thus missed an excellent opportunity to advance their understanding of orogenic processes, long before the global tectonic revolution of the 1960s. He may have been too early a precursor for his ideas to take root and be taken into consideration. It would be fair to his memory and his pioneering effort that the scientific community becomes accustomed to talk about the pre-Triassic fit of the circumAtlantic continents as the Bullard-Choubert fit, similar to the now commonly used term "Beniof-Wadati zones".

Acknowledgements. This text was drawn up on the impulse of Xavier Le Pichon with Hank Frankel's encouragement. It was reviewed by Philippe Huchon and Michel Faure who were both relevant in their comments and benevolent in their conclusions; two other anonymous reviewers showed great goodwill. On behalf of the French Geological Society, Laurent Jolivet supported our initial project right away, while Solange Chaimbault was doing everything necessary to get the copyright of Choubert's initial paper. Elisabeth, Georges and Pierre Choubert, as well as Alexandre, Marion and Michel Schuberth gave permission to the French Geological Society to reproduce text and figures from the article of their uncle Boris. Finally, thanks to Félix Nolleau, the text presented above is written in a language much more polished and idiomatic than that of the initial manuscript. May everyone be assured of the authors' gratitude.

\section{References}

Allen PM. 1969. The geology of part of an orogenic belt in western Sierra Leone, West Africa. Geologische rundschau 58(2): 588-620. Ampferer O. 1906. Über das Bewegungsbild von Faltengebirgen. Jahrbuch der Geologischen Reichsanstalt 56(3-4): 539-622.

Andrault D, Pesce G, Manthilake G, et al. 2018. Deep and persistant melt layer in the Archean Mantle. Nature Geosciences 11: 139143.

Argand E. 1924. La tectonique de l'Asie. Comptes Rendus XIIIe Congrès Géologique International 1922: 171-372.

Aubouin J. 1961. Propos sur les géosynclinaux. Bull Soc géol Fr 7(3): 629-702.

Aubouin J. 1965. Geosynclines. Amsterdam, Oxford, New-York, Tokyo: Elsevier ed., $335 \mathrm{p}$

Baker HB. 1912. Origin of continental forms, II. Michigan Academy Sciences Annual Report 14: 116-141.

Baker HB. 1913a. Origin of continental forms, II. Michigan Academy Sciences Annual Report 15: 107-113.
Baker HB. 1913b. Origin of continental forms, IV. Michigan Academy Sciences Annual Report 15: 26-32.

Baker HB. 1914. Origin of continental forms, V. Michigan Academy Sciences Annual Report 16: 99-103.

Ballèvre M, Bosse V, Dabard M-P, et al. 2013. Histoire géologique du Massif armoricain: actualité de la recherche. Bulletin Société géologique minéralogique Bretagne (D) 10-11: 5-96.

Benioff H. 1949. Seismic evidence for the fault origin of oceanic deeps. Geological Society of America Bulletin 60(12): 1837 1856.

Bertrand H. 1987. Le magmatisme tholéitique continental de la marge ibérique, précurseur de l'ouverture de l'Atlantique Central: les dolérites du dyke de Messejana-Plasencia (Portugal-Espagne). Comptes rendus de l'Académie des sciences, série 2, 304, 6, 215-220.

Bertrand H, Dostal J, Dupuy C. 1982. Geochemistry of early Mesozoic tholeiites from Morocco. Earth and Planetary Sciences Letters 58: 225-239.

Brouwer HA. 1921. De alkaligesteenten van de Serra do Gericino ten Noordwesten van Rio de Janeiro en de overreenkomst der eruptiefgesteenten van Brasilie en Zuid-Afrika. Komink Akademie van Wetenschappen te Amsterdam 29: 1005-1020.

Bullard E, Everett JE, Smith AG. 1965. The fit of the continents around the Atlantic. Phil Trans R Soc Lond A258(1088): 41-51.

Burke K, Dewey JF. 1973. An outline of Precambrian plate development. In: Tarling DH, Runcorn SK, Eds. Implications of continental drift to the earth sciences, Vol. 2. London: Academic Press, pp. 1035-1045.

Carey SW. 1958. The tectonic approach to continental drift. In: University of Tasmania, Geology Department, \& Carey S.W. Continental Drift: A Symposium held in March 1956, 177-358.

Choubert B. 1935. Recherche sur la genèse des chaînes paléozoïques et antécambriennes. Rev Géogr phys Géol dyn VIII 1: 5-50.

Choubert B. 1981. Aperçu de l'évolution des idées concernant la formation de la croûte terrestre d'Alfred Wegener à nos jours. Geologische rundschau 70(1): 40-49.

Dalziel IWD. 1991. Pacific margins of Laurentia and East AntarticaAustralia as a conjugate rift pair: evidence and implications for an Eocambrian supercontinent. Geology 19: 598-601.

Dalziel IWD. 1997. Neoproterozoic-Paleozoic geography and tectonics: review, hypothesis and environmental speculation. Geol Soc America Bull 109: 16-42.

Demay A. 1934a. Contribution à la synthèse de la chaîne hercynienne d'Europe. Évolution stratigraphique et orogénique du géosynclinal hercynien. Rev Géog phys Géol dyn VII, 191-221.

Demay A. 1934b. Contribution à la synthèse de la chaîne hercynienne d'Europe. Étude du plan axial de l'évolution et de l'orogenèse hercynienne. Bull Soc géol France (5), IV, 311-345.

Dives P. 1933. La dérive des continents et les mouvements intratelluriques. Dunod.

Durand-Delga M. 2006. Trois essais de tectonique globale avant la lettre, par Léonce Elie de Beaumont, Eduard Suess et Alfred Wegener. Travaux COFRHIGEO 3(20): 75-103.

Du Toit AL. 1926. The Geology of South Africa. London: Oliver and Boyd.

Du Toit AL. 1937. Our wandering continents. A hypothesis of continental drifting. Edinburgh: Oliver \& Boyd.

Du Toit A, Reed FRC. 1927. A geological comparison of South America with South Africa. Carnegie Institution Washington Publication, 381.

Faure M. 2013. La chaîne varisque en France. Université d'Orléans. https://www.univ-orleans.fr/sites/default/files/OSUC/documents/ chaine_varisque_france.pdf. 
Faure M, Xian-Hua Li, Wei Lin. 2017. The northwest-directed "Bretonian phase" in the French Variscan Belt (Massif Central and Massif Armoricain): a consequence of the early carboniferous Gondwana-Laurussia collision. Comptes Rendus Géoscience 349 (3): 126-136.

Gagnebin E. 1922. La dérive des continents selon la théorie d'Alfred Wegener. Revue générale sciences pures et appliquées 33(10): 293-304.

Gaudant J. 1989. Principaux résultats de l'enquête sur la dérive des continents. Travaux COFHIGEO 3(3): 21-36.

Gaudant J. 1995. La réception de l'idée de dérive des continents en France et en Suisse romande: les enseignements d'une enquête. Mém Soc géol France 168: 129-138.

Gignoux M. 1925. Les théories de Wegener. À propos de la traduction française de son ouvrage. Revue générale sciences pures et appliquées 36(5): 139-142.

Harper DAT, Bruton DL, Rasmussen CMØ. 2008. The Otta brachiopod trilobite fauna: palaeogeography of Early Palaezoic terranes and biotas across Baltoscandia. Fossils and Strata 54: $31-40$.

Haug E. 1907-1911. Traité de géologie. Paris : Armand Colin éd., 4 tomes, $2024 \mathrm{p}$.

Holmes A. 1928. Radioactivity and continental drift. Nature 122: 431-433.

Holmes A. 1929. A review of the continental drift hypothesis. Mining Magazine 40: 205-209, 286-288, 340-347.

Holtedahl O. 1960. Geology of Norway, Norges Geologiske Undersokelse 208: 151-169.

Jacob CH. 1925. Les théories tectoniques nouvelles: E. Argand - A. Wegener. Annales de Géographie 34(188): 97-112.

Knight KB, Nomade S, Renne PR et al. 2004. The central atlantic magmatic province at the Triassic-Jurassic boundary: paleomagnetic and 40Ar/39Ar evidence from Morocco for brief, episodic volcanism. Earth and Planetary Science Letters 228(1): 143-160.

Kornprobst J. 2017. Boris Choubert: The forgotten fit of the circumAtlantic continents. Comptes Rendus Geosciences 349(1): 42-48.

Kossmat F. 1927. Gliederung des Variszsichen Gebirgebaues. Abdhandlungen Sächsiches Geologisches Lamdesamtes 1: 1-39.

Letsch D. 2017. A pioneer of Precambrian geology: Boris Choubert's fit of the continents across the Atlantic (1935) and his insight into the Proterozoic tectonic structure of the West African Craton and adjacent areas. Precambrian Research 294: 230-243.

Le Vigouroux $\mathrm{Ph}$. 2011. La première guerre mondiale. Incidence sur la réception de la théorie de Wegener. Travaux COFRHIGEO 325 (8): 187-206.

Le Vigouroux Ph, Gohau G. 2016. De l'amateurisme en géologie : la réception française de la théorie de la dérive des continents (1920-1950). Gesnerus 73(2): 337-359.

Maack R. 1934. Die Gondwanaschichten in Südbrasilien und ihre Beziehungen zur Kaoko formation Südwest-Afrika. Zeitschrift der Gesellschaft für Erdkunde zu Berlin 5(6): 194-222.
Marzoli A., Renne P.R., Piccirillo E.M. et al. 1999. Extensive 200million-year-old continental flood basalts of the Central Atlantic magmatic province. Science 284: 616-618.

Meinhold G, Şengör AMC. 2018. A historical account of how continental drift and plate tectonics provided the framework for our currentunderstanding of paleogeography. Geol Magazine, https://doi.org/10.1017/S0016756818000063.

Oliver J, Isaks B. 1967. Deep Earthquake zones anomalous structures in the upper mantle and the lithosphere. Journal of Geophysical Research 72(16): 4259-4275.

Pin Ch, Vielzeuf D. 1983. Granulites and related rocks in Variscan median Europe: a dualistic interpretation. Tectonophysics 93(1-2): 47-74.

Porch D. 1984. The Conquest of the Sahara. Farrar, New York: Straus and Giroux, $332 \mathrm{p}$.

Schuchert C. 1924. The continental displacement hypothesis as viewed by Du Toit. American Journal of Sciences 16: 266-274.

Schuchert C. 1928. The hypothesis of continental displacement. Smithsonian Report for 1928, 249-282.

Scotese CR. 2004. A continental drift flipbook. The Journal of Geology 112: 729-741.

Şengör AMC. 1979. Mid-Mesozoic closure of Permo-Triassic Tethys and its implications. Nature 279: 590-593.

Şengör AMC. 2014. Pangäische Spiele. Mitteilungen des Naturwissenschaftlichen Vereines für Steiermark 143: 7-48.

Sibuet J-C. 1974. Histoire tectonique du Golfe de Gascogne. 297-312. http://archimer.ifremer.fr/doc/00000/5134/

Sougy J. 1962. West African fold belt. Geological Society of America Bulletin 73: 871-876.

Stille H. 1927. Uber Westmediterrane Gebirszusammenhänge. Abhandlungen der Gesellschaft der Wissenschaften zu Göttingen, Math. - Phys.Klasse III, 12. Beiträge zur Geologie der Westlichen Maditerrangebiete, 3 (12): 1-62.

Suess E. 1885-1909. Das Antlitz der Erde. Tempsky, Prag und Freitag ed., Leipzig, 168 pp.

Taylor FB. 1910. Bearing of the tertiary mountain belt on the origin of the Earth's plan. Geological Society of America Bulletin 21: 179-226.

Termier P. 1924. La dérive des continents. Revue Scientifique 62(9): 257-267.

Wadati K. 1935. On the activity of deep-focus earthquakes in the Japan Islands and neighbourhoods. Geophysical Magazine 8: 305-325.

Wegener A. 1912. Die Entstehung der Kontinente. Geologische Rundschau 3: 276-290.

Wegener A. 1915. Die Entstehung der Kontinente und Ozeane. Friedriech Vieweg \& Sohn ed.

Wegener A. 1929. Die Entstehung der Kontinente und Ozeane. $5^{\mathrm{e}}$ édition. Traduction française, Nizet \& Bastard, Paris 1937.

Walcott CD. 1891. Correlation papers, Cambrian. Bulletin US Geological Survey 81: 447.

Wilson JT. 1966. Did the Atlantic close and then re-open? Nature 211: 676-681.

Cite this article as: Kornprobst J, Àbalos B, Barbey P, Boullier A-M, Burg J-P, Capdevila R, Claesson S, Cordani U, Corrigan D, Gabrielsen RH, Gil-Ibarguchi JI, Johansson Â, Letsch D, Le Vigouroux P, Upton B. 2018. Boris Choubert: Unrecognized visionary geologist, pioneer of the global tectonics, BSGF - Earth Sciences Bulletin 189: 7. 